\title{
Soil preparation and forage sowing time for crop- livestock integration in corn culture
}

\author{
Luiz Fernando de Andrade Fritsch ( $)$; Marco Antonio Camillo de Carvalho (2*); Rivanildo Dallacort ( $\left.{ }^{3}\right)$; \\ Cristiano Santos ( $\left.{ }^{3}\right)$ \\ (') Instituto de Defesa Agropecuária do Estado de Mato Grosso (INDEA MT), Rua 02, s/n, Ed. Ceres, 2. Andar, CPA, 78050-970 \\ Cuiabá (MT), Brasil. \\ (2) Universidade do Estado de Mato Grosso (UNEMAT), Curso de Agronomia, Av. Perimetral Rogério Silva, s/n, Residencial \\ Flamboyant, 78580-000 Alta Floresta (MT), Brasil. \\ (3) Universidade do Estado de Mato Grosso (UNEMAT), Curso de Agronomia, Rodovia MT 358, km 7, Jardim Aeroporto, 78300-000 \\ Tangará da Serra (MT), Brasil. \\ (*) Corresponding author: marcocarvalho@unemat.br
}

Received: Oct. 15, 2011; Accepted: Sept. 12, 2012

\begin{abstract}
This work was carried out during the 2008/2009 crop season, in an Oxisol. It was used a split-plot arrangement design, with each plot corresponding to a different soil preparation system and each split-plot corresponding to a different sowing time of the forage Brachiaria brizantha Stapf. The soil preparation systems were: heavy harrowing (HH), disk plough (DP), chisel plough (CP) and no-till (NT), and the forage sowing times were: 0, 8, 16 and 25 days after sowing (DAS) of corn, arranged in 16 treatments with 3 replicates. The productive and vegetative characteristics of the corn were evaluated. Soil preparations have influenced plant height and the first ear height, with the highest value found for the heavy harrow treatment. Forage sowing time had no influence on vegetative characteristics of the corn and productive characteristics were not influenced by the soil preparations. The forage sowing time had influence on corn productivity, causing decrease in competition with corn forage from 5 DAS. The productivity was highly correlated with the number of grains per ear.

Key words: Zea mays L., Brachiaria brizantha Stapf. cv Piata, intercropping, ploughing.
\end{abstract}

\section{Preparos de solo e épocas de semeadura de forragem para integração lavoura- pecuária na cultura do milho}

\section{Resumo}

Este trabalho foi desenvolvido, na safra 2008/2009, em Latossolo Vermelho-Amarelo, distrófico. Foi utilizado delineamento em parcelas subdivididas, em que cada parcela correspondeu a diferentes sistemas de preparo do solo e as subparcelas corresponderam a diferentes épocas de semeadura da forrageira Brachiaria brizantha Stapf. Os sistemas de preparo do solo foram os seguintes: grade aradora (GA), arado de discos (AD), cultivo mínimo (CM) e semeadura direta (SD); as épocas de semeadura da forrageira foram feitas a 0, 8, 16 e 25 dias após a semeadura do milho (DAS), totalizando 16 tratamentos, com três repetições. Avaliaram-se as características vegetativas e produtivas da cultura do milho. Os preparos de solo influenciaram a altura de plantas e de inserção da primeira espiga, sendo os maiores valores observados no tratamento com grade aradora; a época de semeadura da forrageira não teve influência sobre as características vegetativas; os diferentes preparos do solo não influenciaram as características produtivas. A época de semeadura da forrageira teve influência somente sobre a produtividade do milho, provocando diminuição da competição entre a forrageira e o milho a partir de cinco DAS. A produtividade foi altamente correlacionada com o número de grãos por espiga.

Palavras-chave: Zea mays L., Brachiaria brizantha Stapf. cv. Piatã, consórcio, aração.

\section{INTRODUCTION}

In northern Mato Grosso State, there has been a deforestation process causing by the agriculture and livestock use of the land in the last 30 years, with areas largely degraded or in some stage of degradation (CARVALHO et al., 2011). The inadequate management and the lack of nutrients reposition are important factors that have accelerated the degradation process (MACEDO, 2009). This situation is worsened by lack of infrastructure, soil and technical limitations and the need of financial investment to increase zootechnical levels and profitability (BROCH et al., 2008).

In agricultural areas, monoculture and inadequate cultural practices, such as the soil preparation with successive harrowing, have caused productivity decrease 
and degradation of soil and natural resources (MACEDO, 2009). In those cases, crop-livestock integration system become an option to pasture and agricultural areas reform, aiming to rationally maximize land use, infrastructure, labor and diversity, increasing the production, minimizing costs, decreasing risks and adding values to agricultural products through the resources and benefits that one activity provides to another (ZANine et al., 2006).

Every tillage alters the physical properties of the soil, but such alterations are more evident in conventional systems compared to conservationist systems of soil preparation, and these has influence on plants development (BERTOL et al., 2004) and nutrients availability in the soil. Therefore, the planted area with no-till system in Brazil has increased in the last few years, taken as the most sustainable system related to soil conservation and nutrients cycling by crop cultures (Pavinato et al., 2009).

The use of intercropping annual cultures with forage has also been a good sustainable alternative (ZANine et al., 2006), and among the annual cultures, corn has been highlighted in this system, presenting advantage in competition with other plants, such as Brachiaria spp. as verified by SiLva et al. (2004), evaluating development rates in the early periods of plant development.

The choosing of a forage sowing time must aim to minimize the competition with the corn and also enable, after the corn crop, efficient forage recuperation (Pequeno et al. 2006; Chioderoli et al., 2010). The height of plants has direct influence in grains loss and cleanness in mechanized harvesting, and in other factors linked to it, especially in the first ear insertion, since higher plants have higher ear insertion, presenting harvest advantages (Possamai et al., 2001).

In this context of crop-livestock integration and intercropping systems, many questions are raised, such as the best soil preparation system and the correct forage sowing time, which this work aimed to verify.

\section{MATERIAL AND METHODS}

This work was carried out during the 2008/2009 crop season ( $09^{\circ} 51^{\prime} 42^{\prime \prime} \mathrm{S}, 5^{\circ} 04^{\prime} 07^{\prime \prime} \mathrm{W}$, and altitude of $282 \mathrm{~m}$ ), in a tropical wet climate, with a pronounced dry season, type Awi (Köppen, 1948), and monthly average temperature ranging from 23.8 to $26.1^{\circ} \mathrm{C}$ (SANTOS, 2000). Local annual precipitation average is $2,750 \mathrm{~mm}$ (CARVALHO et al., 2011), which can exceed 2,800 mm (Sirva et al., 2011). The soil was classified as Oxisol by the USDA/NRCS (SoIL..., 2010).

It was used a split-plot arrangement design, with each plot with a different soil preparation system and each splitplot with a different sowing time of the forage, arranged in 16 treatments with 3 replicates. The plots had a dimension of $4.5 \mathrm{~m}$ (6 lines) wide and $5.0 \mathrm{~m}$ long, using for evaluations the two central lines, from $0.5 \mathrm{~m}$ of the borders.
The four soil preparation were: heavy harrow $(\mathrm{HH})$ two harrowing with a 16 disks harrow $(8$ smooth and 8 notched) of motor traction, depth of $10-15 \mathrm{~cm}$, and two harrowing with a 28 disks harrow; disk plough (DP) - one ploughing with a 3 reversible disks plough of motor traction, depth of $20-25 \mathrm{~cm}$, and two harrowing with a 28 disks harrow; chisel plough (CP) - one ploughing with a 5 tine subsoiler chisel plough of motor traction, depth of $20-25 \mathrm{~cm}$, and one harrowing with a 28 disks harrow; and no-till (NT) - direct sowing with no soil preparation.

In December 11, 2008, the corn and first forage sowing and first fertilizing was done with a manual furrower. The forage used was Brachiaria brizantha Stapf. cv BRS Piata, which was sowed at $0,8,16$ and 25 days after the sowing of corn (DAS) in the line and between the lines of corn. The corn seed chosen was the triple hybrid 2B688 (Dow Agrosciences) characterized by plants with $2.10 \mathrm{~m}$ high, and sowed with $0.75 \mathrm{~m}$ between lines with 5 plants per meter.

Fertilization was done according to soil analyses and recommendations of Ribeiro et al. (1999). It was applied $400 \mathrm{~kg} \mathrm{ha}^{-1}$ of a formulation of NPK (40:30:10) at corn sowing and the same amount of the formulation plus $120 \mathrm{~kg} \mathrm{ha}^{-1}$ of nitrogen (urea), when the corn plants were with five developed leaves.

For weed control before sowing it was used the herbicide glyphosate $\left(480 \mathrm{~g} \mathrm{ha}^{-1}\right)$ in the no-till and chisel plough plots. The insect control was necessary for Spodoptera frugiperda, which was done with the insecticide diflubenzurom (100 $\left.\mathrm{g} \mathrm{ha}^{-1}\right)$.

In flowering stage it was verified the corn plants height from soil surface up to flag leaf insertion. After physiological maturation (130 DAS) it was verified the first ear insertion height from soil surface, ear diameter, length and weight without straw, number of grains per ear (average from 10 ears per treatment, collected randomly), grain yield (extrapolated from weight of the ears in the evaluated area, converted to $\mathrm{kg} \mathrm{ha}^{-1}$ at $13 \%$ of humidity), and the weight of 100 grains (average from 4 sample of 100 grains weight per treatment corrected for $13 \%$ humidity). For these quantifications and evaluations there were used a caliper rule, measuring tape, scales and an incubator.

The data were subjected to variance analysis and average comparison by the Tukey test at 5\% of probability, and for the polynomial regression study of quantitative factors it was used the Sisvar software (Ferreira, 2000).

\section{RESULTS AND DISCUSSION}

Regarding the corn vegetative characteristics evaluated, it was verified that the time of sowing of forage influenced only the length of ears (Table 1), and there were no interaction between the factors soil preparation and forage sowing time for those characteristics. However, soil 
preparation had influence on plant height and first ear insertion height.

The highest value of plant height was found in the treatment with heavy harrow, not differing from the treatments with disk plough and chisel plough. The highest values for first ear insertion were also found in the treatment with heavy harrow, not differing from the chisel plough and no-till systems (Table 1).

These results partly differ from those found by Possamai et al. (2001), who studying winter corn crop, observing in no-till system the highest values of plant height and first ear insertion height, and plants developing earlier than other treatments, attributing this to the better temperature, humidity and luminosity.

In the present study the results can be explained by the low quality and quantity of the mulching, the short time of no-till system implementation in the used area, and the higher compaction of soil, disfavoring plants in no-till system in these conditions. Custodio et al. (2003) report that the deeper soil preparation provides some benefits such as strength reduction of growth of roots, the depth increase of roots, the reducing of the oxygen stress in case of excess water, the increase production of corn and soybeans and the reducing of water stress effect.

Soil compaction is one of the great obstacles to yield increase, and the soil penetration resistance is greater in no-till system (Ralisch et al., 2008). AlbuQuerque et al. (2001) studying soil physical modifications with conventional soil preparation and no-till systems, observed

Table 1. Corn vegetative characteristics ${ }^{1}$ according to soil preparation system and Brachiaria brizantha Stapf. sowing time in intercropping system for crop-livestock integration

\begin{tabular}{lllll|} 
& $\begin{array}{c}\text { PH } \\
(\mathbf{c m})\end{array}$ & $\begin{array}{c}\text { FEIH } \\
(\mathbf{c m})\end{array}$ & $\begin{array}{c}\text { EL } \\
(\mathbf{c m})\end{array}$ & $\begin{array}{c}\text { ED } \\
(\mathbf{c m})\end{array}$ \\
\hline Soil Preparation & & & & \\
Heavy Harrow & $1.99 \mathrm{a}^{(1)}$ & $1.01 \mathrm{a}$ & 14.85 & 5.18 \\
\hline Disk Plough & $1.91 \mathrm{ab}$ & $0.85 \mathrm{~b}$ & 14.07 & 4.98 \\
\hline Chisel Plough & $1.91 \mathrm{ab}$ & $0.90 \mathrm{ab}$ & 14.65 & 5.16 \\
\hline No-Till & $1.85 \mathrm{~b}$ & $0.94 \mathrm{ab}$ & 13.74 & 5.07 \\
\hline Value of F & $9.16^{*}$ & $3.14^{*}$ & $2.10 \mathrm{~ns}$ & $1.51 \mathrm{~ns}$ \\
\hline DMS (Tukey 5\%) & 0.09 & 0.13 & 1.17 & 0.21 \\
\hline Sowing Time & & & & \\
\hline 0 DAS & 1.91 & 0.91 & 14.06 & 5.07 \\
\hline 8 DAS & 1.93 & 0.97 & 13.73 & 5.01 \\
\hline 16 DAS & 1.93 & 0.90 & 14.69 & 5.16 \\
\hline 25 DAS & 1.91 & 0.92 & 14.83 & 5.14 \\
\hline Value of F & $0.19 \mathrm{~ns}$ & $0.76 \mathrm{~ns}$ & $3.01^{*}$ & $1.43 \mathrm{~ns}$ \\
\hline Linear regression & $0.01 \mathrm{~ns}$ & $0.06 \mathrm{~ns}$ & $6.01^{* *}$ & $2.14 \mathrm{~ns}$ \\
\hline Quadratic regression & $0.58 \mathrm{~ns}$ & $0.48 \mathrm{~ns}$ & $0.61 \mathrm{~ns}$ & $0.10 \mathrm{~ns}$ \\
\hline Interaction (Value of F) & $2.04 \mathrm{~ns}$ & $0.78 \mathrm{~ns}$ & $0.72 \mathrm{~ns}$ & $0.85 \mathrm{~ns}$ \\
\hline Variation Coefficient (\%) & 4.34 & 13.71 & 7.24 & 3.98
\end{tabular}

PH: plant height; FEIH: first ear insertion height; EL: ear length; ED: ear diameter. DAS: days after corn sowing. ( $\left.{ }^{1}\right)$ Values followed by the same letter have no difference from each other at $5 \%$ of probability by Tukey test; ns: non significant by $\mathrm{F}$ test; ${ }^{*}$ significant at $5 \%$ of probability by $\mathrm{F}$ test. negative effect of no-till system on corn yield and correlation between growth and compaction.

Spike length was increased with the delay in forage sowing time, and this behavior fit the linear model $y=13.51+0.328 x, r^{2}=0.693$ (Figure 1).

It was verified that the soil preparation had no influence in any of the corn productive characteristics evaluated (Table 2). Also, there were no interaction between the factors soil preparation and forage sowing time for those characteristics. However, the corn yield was influenced by the forage sowing time.

There is great variation in the literature regarding the productive characteristics of corn on different soil tillage. These variations of results are related to the features present in each study area, such as time of use of no-tillage system, soil physical characteristics, presence and amount of mulch, water deficit along the culture, among others.

The soil preparation results agree with those found by Bertolini et al. (2006), who have observed no difference in productivity among no-till and chisel plough, attributing this to the fact that the no-till system had been used for only three years in their area. However, SiLveira and Stone (2003), evaluating three systems of soil preparations (moldboard plough, heavy harrow and no-till), observed that the systems had no effect on soybean yield, but it had influenced corn and swath cultures, with greater yield in the moldboards plough treatments. Possamai et al. (2001) found highest values in no-till system, attributing this to the good mulching, which provided lower water loss and soil temperature fluctuation, enabling better development of plants despite the no-till system had been implemented only two years before.

Considering other factors such as the occurrence of unexpected warm dry days periods, CarvalHo et al. (2004) verified that the conventional system provided higher productivity of corn compared to no-till system, attributing this fact to the improvement that the soil tillage provide to the root system and development of corn, once the lower soil density allow a better plants resistance to drought periods, which usually occur after flowering.

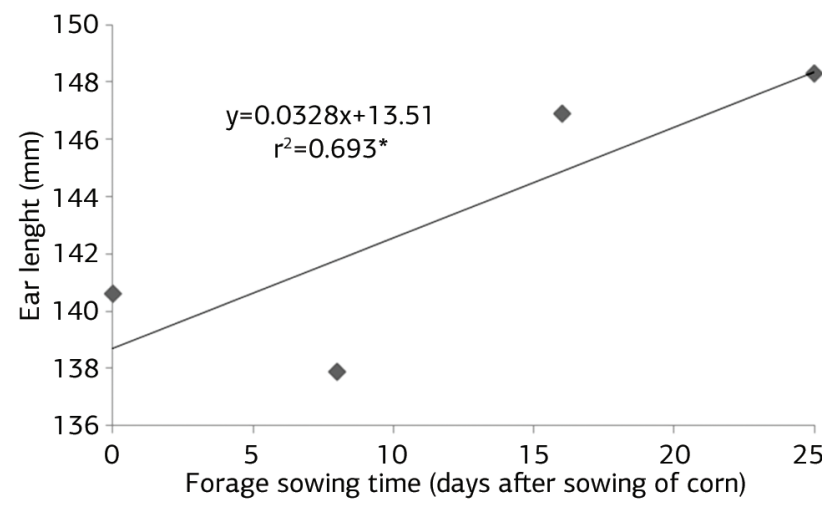

Figure 1. Corn ear length $(\mathrm{mm})$ as a function of forage sowing time (days after sowing of corn). ${ }^{*}$ significant at $5 \%$ of probability by $\mathrm{F}$ test 
It was verified no influence of the forage sowing time on the ear weight, number of grains per spike and weight of 100 grain, however, it was observed an increasing tendency for these characteristics with the delay in forage sowing time. There was also no influence of forage sowing time on the number of grains per ear, however, it was observed a high positive correlation between the number of grains per ear and yield, with $\mathrm{r}=0.9307(\mathrm{p}<0,01)$, indicating a possible dependence between these characteristics.

In figure 2 it is presented the behavior of yield as a function of forage sowing time, that presented a quadratic model $y=7878.4-43.725 x+4.3809 x^{2}\left(r^{2}=0.9134\right)$. Analyzing the behavior of the trend line between productivity and forage sowing time (Figure 2), it appears that the minimum point of the curve was at 5 DAS, where productivity would be $8,205 \mathrm{~kg} \mathrm{ha}^{-1}$, indicating that for the conditions of this study, first five days were those where competition between the forage and corn were the most intense and the situation tends to be reduced after this period.

The greatest yields observed in the treatments after 5 DAS can be explained by the lower level of competition with the forage, not having its initial development influenced by the shading, once the main crop was already established in the area. Moreover, the treatment with corn and forage planted simultaneously had the lowest productivity, possibly because the high competition for light, water and nutrients.

Silva et al. (2004) observed that the forage has a slower initial growth rate and is unfavorable influenced by the competition with corn, which has advantage in competition with smaller plants due to its higher rates of biomass production in the initial development phase, hence its higher capacity for interception of photosynthetical radiation along its canopy and causing shading on forage species.

The results found for sowing time were similar to those found by Richart et al. (2010), studying sowing time for Brachiaria ruziziensis intercropping with winter corn $(0,15$ e $30 \mathrm{DAS})$, verifying influence in weight of 1,000 grains and competitive advantage at 15 and 30 DAS. However, different results were found by PEQueno et al. (2006) in a study conducted in Gurupi, Tocantins State. They verified that the forage sowing at sowing of corn or at 16, 32 or 48 DAS of corn had no effect on corn grain or green matter production.

An option to minimize the problem of corn productivity with simultaneous sowing is showed by MACEDO (2009), who suggested after the corn sowing with Brachiaria spp., in the early growth stages of Brachiaria, an application of an herbicide selective for corn, in sub

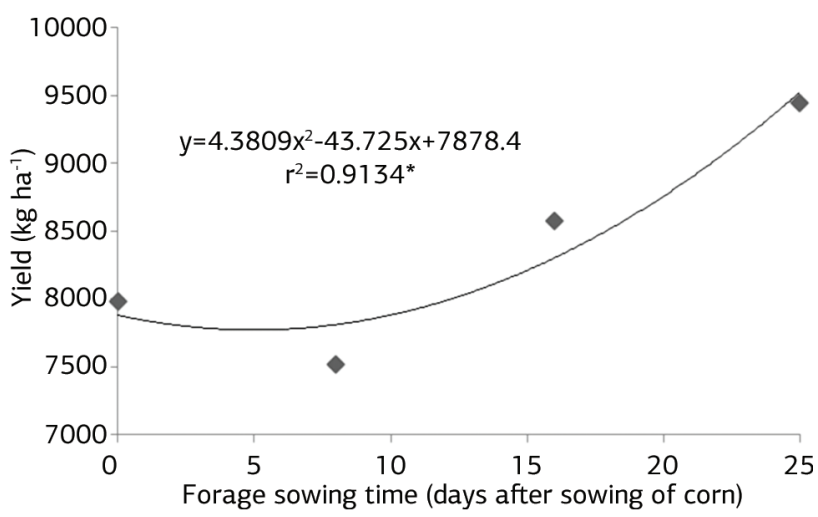

Figure 2. Corn yield $\left(\mathrm{kg} \mathrm{ha}^{-1}\right)$ as a function of forage sowing time (days after sowing of corn). * significant at $5 \%$ of probability by $\mathrm{F}$ test

Table 2. Corn productive characteristics according to soil preparation system and Brachiaria brizantha Stapf. sowing time in intercropping system for crop-livestock integration

\begin{tabular}{|c|c|c|c|c|}
\hline & $\begin{array}{l}E W \\
(g)\end{array}$ & $\begin{array}{c}\text { NG } \\
\text { (unid.) }\end{array}$ & $\begin{array}{l}\text { P100 } \\
\text { (g) }\end{array}$ & $\begin{array}{c}\text { GY } \\
\left(k^{\prime} \mathrm{ha}^{-1}\right)\end{array}$ \\
\hline \multicolumn{5}{|l|}{ Soil Preparation } \\
\hline Heavy Harrow & 167.91 & 534.76 & 27.61 & 8.882 \\
\hline Disk Plough & 148.75 & 493.39 & 26.30 & 8.042 \\
\hline Chisel Plough & 158.16 & 511.94 & 26.76 & 8.284 \\
\hline No-Till & 177.66 & 504.39 & 26.01 & 8.305 \\
\hline Value of $F$ & $0.80 \mathrm{~ns}$ & $1.08 \mathrm{~ns}$ & $2.16 \mathrm{~ns}$ & $1.27 \mathrm{~ns}$ \\
\hline DMS (Tukey 5\%) & 53.47 & 64.91 & 1.83 & 1.214 \\
\hline \multicolumn{5}{|l|}{ Sowing Time } \\
\hline O DAS & 153.00 & 504.44 & 26.31 & 7.979 \\
\hline 8 DAS & 168.16 & 474.88 & 26.71 & 7.516 \\
\hline 16 DAS & 164.58 & 528.67 & 26.76 & 8.578 \\
\hline 25 DAS & 166.75 & 536.49 & 26.90 & 9.440 \\
\hline Value of $F$ & $0.25 \mathrm{~ns}$ & $2.74 \mathrm{~ns}$ & $0.28 \mathrm{~ns}$ & $6.92^{* *}$ \\
\hline Linear regression & $0.36 \mathrm{~ns}$ & $3.97 \mathrm{~ns}$ & $0.72 \mathrm{~ns}$ & $14.88^{* *}$ \\
\hline Quadratic regression & $0.22 \mathrm{~ns}$ & $1.23 \mathrm{~ns}$ & $0.08 \mathrm{~ns}$ & $4.40^{*}$ \\
\hline Interaction (Value of F) & $0.58 \mathrm{~ns}$ & $0.78 \mathrm{~ns}$ & $1.57 \mathrm{~ns}$ & $0.86 \mathrm{~ns}$ \\
\hline Variation Coefficient (\%) & 29.52 & 11.44 & 6.19 & 13.05 \\
\hline
\end{tabular}

EW: ear weight; NG: number of grains per ear; P100: weight of 100 grains; GY: Grain Yield; DAS: days after corn sowing. 
dose for partial suppression of Brachiaria, in order to decrease its growth favoring the corn culture, improving grain production. However, despite the Brachiaria mass reduction, afterwards it must be able to reestablish, cover adequately the soil, and after the corn harvesting it must has its growing normalized.

BROCH et al. (2008) also observed that the herbicide application decrease forage growth avoiding significant losses on corn crop due competition. They also present an option of forage sowing together the corn sowing at 8 to $10 \mathrm{~cm}$ depth, considering that there will not be a competition with the forage due the sowing depth.

\section{CONCLUSION}

Regarding the vegetative characteristics evaluated, the soil preparation systems have influenced the plant height and first ear height, with best results for the heavy harrow treatment. The forage sowing time had influence only on the length of ear, with an increasing linear tendency. The corn productive characteristics evaluated were not influenced by the preparation of the soils. The forage sowing time had influence only on corn yield, with the forage sowing from 5 DAS causing yield decrease due to the competition with the corn. The productivity was highly correlated with the number of grains per ear.

\section{REFERENCES}

ALBUQUERQUE, J.A.; SANGOI, L.; ENDER, M. Efeitos da integraçáo lavoura-pecuária nas propriedades físicas do solo e características da cultura do milho. Revista Brasileira de Ciência de Solo, v.25, p.717-723, 2001.

BERTOL, I.; ALBUQUERQUE, J.A.; LEITE, D.; AMARAL, A.J.; ZOLDAN JUNIOR, W. Propriedades físicas do solo sob preparo convencional e semeadura direta em rotação e sucessão de culturas, comparadas às do campo nativo. Revista Brasileira de Ciência do Solo, v.28, p.155-163, 2004.

BERTOLINI, E.V.; GAMERO, C.A.; BENEZ, S.H. Desempenho da cultura do milho em diferentes manejos do solo sobre cobertura vegetal de nabiça (Raphanus raphanistrum L.). Energia Agrícola, v.21, p.34-49, 2006.

BROCH, D.L.; BARROS, R.; RANNO, S.K. Consórcio milho safrinha/pastagem. In: FUNDAÇÃO MS. Tecnologia e produção de milho safrinha e cultura de inverno 2008. 4.ed. Maracaju: Fundação MS, 2008. p.15-29.

CARVALHO, M.A.C.; SORATTO, R.P.; ATHAYDE, M.L.F.; ARF, O.; SÁ, M.E. Produtividade do milho em sucessão a adubos verdes no sistema de plantio direto e convencional. Pesquisa Agropecuária Brasileira, v.39, p.47-53, 2004.

CARVALHO, M.A.C.; YAMASHITA, O.M.; ROQUE, C.G.; NOETZOLD, R. Produtividade de arroz no sistema integração lavoura-pecuária com o uso de doses reduzidas de herbicida. Bragantia, v.70, p.33-39, 2011.

CHIODEROLI, C.A.; MELLO, LUIZ M. M.; GRIGOLLI, P.J.; SILVA, J.O.R.; CESARIN, ANDRÉ L. Consorciação de braquiárias com milho outonal em plantio direto sob pivô central. Engenharia Agrícola, v.30, p.1101-1109, 2010.

CUSTÓDIO, D.P.; PASQUALETTO, A.; OLIVEIRA, I.P. Comportamento de cultivares de milho (Zea mays) e sistemas de cultivo. Estudos, v.30, p. 1793-1804, 2003.

FERREIRA, D.F. Sistema de análises de variância para dados balanceados. Lavras: UFLA, 2000. (SISVAR 4. 1. pacote computacional).

KÖEPPEN, W. Climatologia: con un estudio de los climas de la Tierra. 3.ed. Cidade do México: Fondo de Cultura Economica, 1948. 478p.

MACEDO, M.C.M. Integração lavoura e pecuária: o estado da arte e inovaçóes tecnológicas. Revista Brasileira de Zootecnia, v.38, p.133-146, 2009.

PAVINATO, P.S.; MERLIN, A.; ROSOLEM, C.A. Disponibilidade de cátions no solo alterada pelo sistema de manejo. Revista Brasileira de Ciência do Solo, v.33, p.1031-1040, 2009.

PEQUENO, D.N.L.; MARTINS, E.P.; AFFERRI, F.S.; FIDELIS, R.R.; SIQUEIRA, F.L.T. Efeito da época de semeadura da Brachiaria brizantha em consórcio com o milho, sobre características agronômicas da cultura anual e da forrageira em Gurupi, estado do Tocantins. Amazônia, v.2, p.127-134, 2006.

POSSAMAI, J.M.; SOUZA, C.M.; GALVÃO, J.C.C. Sistemas de preparo do solo para o cultivo do milho safrinha. Bragantia, v.60, p.79-82, 2001.

RALISCH, R.; MIRANDA, T.M.; OKUMURA, R.S.; BARBOSA, G.M.C.; GUIMARÁES, M.F. SCOPEL, E.; BALBINO, L.C. Resistência à penetraçáo de um Latossolo Vermelho Amarelo do Cerrado sob diferentes sistemas de manejo. Revista Brasileira de Engenharia Agrícola e Ambiental. v.12, p.381-384, 2008.

RIBEIRO, A.C.; GUIMARAES, P.T.G.; ALVAREZ V., V.H. (Ed.). Recomendaçáo para o uso de corretivos e fertilizantes em Minas Gerais. Viçosa: Comissão de Fertilidade do Solo do Estado de Minas Gerais, 1999. 359p.

RICHART, A.; PASLAUSKI, T.; NOZAKI, M.; RODRIGUES, C.; FEY, R. Desempenho do Milho Safrinha e da Brachiaria ruziziensis cv. Comum em Consórcio. Revista Brasileira de Ciências Agrárias, v.5, 497-502, 2010.

SANTOS M.V. Relatório técnico consolidado de clima para o Estado de Mato Grosso, vol. 2. In: Prodeagro: Zoneamento sócioeconômico-ecológico: Diagnóstico sócio - econômico-ecológico do estado de Mato Grosso e assistência técnica na formulação da 2. ${ }^{a}$ aproximação. Cuiabá: SEPLAN-BIRD, 2000. p.20.

SILVA, A.A.; JAKELAITIS, A.; FERREIRA, L.R. Manejo de plantas daninhas no sistema integrado agricultura-pecuária. In: ZAMBOLIM, L.; SILVA, A.A.; AGNES, E.L. Manejo integrado: integração agricultura-pecuária. Viçosa: Universidade Federal de Viçosa, 2004. p.117-169. 
SILVA, A.C.; FERREIRA, L.R.; SILVA, A.A.; PAIVA, T.W.B.; SEDIYAMA, C.S. Efeitos de doses reduzidas de fluazifop-p-butil no consórcio entre soja e Brachiaria brizantha. Planta Daninha, v.22, p.429-435, 2004.

SILVA, A.F.; SCHONINGER, E.L.; MONTEIRO, S.; CAIONE, G.; CARVALHO, M.A.C.; DALCHIAVON, F.C.; NOETZOLD, R. Inoculação com bradyrhizobium e formas de aplicação de cobalto e molibdênio na cultura da soja. Revista Agrarian, v.4, p.98-104, 2011.

SILVEIRA, P.M.; STONE, L.F. Sistemas de preparo do solo e rotaçáo de culturas na produtividade de milho, soja e trigo.
Revista Brasileira de Engenharia Agrícola e Ambiental, v.7, p.240-244, 2003.

SILVEIRA, P.M.; STONE, L.F. Efeitos do sistema de preparo e da rotação de culturas na porosidade e densidade do solo. Revista Brasileira de Ciência do Solo, v.25, p.395-401, 2001.

SOIL Survey Staff. Keys to Soil Taxonomy. 11.ed. Washington: USDA-Natural Resources Conservation Service, 2010. 346p.

ZANINE, A.M.; SANTOS, E.M.; FERREIRA, D.J.; CARVALHO, G.G.P. Potencialidade da integração lavoura-pecuária: relação planta-animal. Revista Electrónica de Veterinaria, v.7, 2006. 